\title{
Synthesis of $C_{2}$-Symmetric Bisphosphines and Their Application in Enantioselective Transition Metal Catalysis
}

\author{
Halil Zeki Gök, ${ }^{1}$ Seda Kılıçarslan, ${ }^{2}$ Yaşar Gök ${ }^{1, *}$
}

\footnotetext{
1 Department of Biomedical Engineering, Faculty of Technology, Mehmet Akif Ersoy University, 15030, Bucak/Burdur, Turkey

2 Department of Chemistry, Faculty of Arts and Sciences, Osmaniye Korkut Ata University, 80000, Osmaniye, Turkey

* Corresponding author's e-mail address: yasar_gok@yahoo.com
}

RECEIVED: February 8, 2018 * REVISED: April 3, 2018 * ACCEPTED: April 9, 2018

\begin{abstract}
C_{2}$-symmetric bisphosphine ligands (with a dioxolane backbone) have been synthesized by using corresponding chiral bromosubstituted hydrobenzoin derivatives in two steps with moderate yields. The last step for desired bisphosphines defined the electronic and steric properties of the chelating atoms by the treatment of aryl or alkyl substituted chlorophosphine compounds in the presence of a base. These synthesized ligands have been evaluated in different catalytic reactions. The first application has been the palladiumcatalyzed enantioselective allylic alkylation which is regarded as a remarkable reaction for forming enantioselective carbon-carbon bond (up to $63 \%$ ee and $98 \%$ chemical yield). The ruthenium-catalyzed enantioselective transfer hydrogenation reaction has been the second application for the evaluating of the catalysts (up to $>99 \%$ conversion with no enantioselectivity).
\end{abstract}

Keywords: synthesis, bisphosphine, catalysis, chirality, enantioselectivity.

\section{INTRODUCTION}

ARBON-CARBON and carbon-heteroatom bonds forming reactions such as allylic substitutions have become part of modern organic chemistry. ${ }^{[1-7]}$ In this context, there is a remarkable attention in this type of synthesis and over the past few years, extensive researches have been carried out in order to develop efficient chiral ligands. ${ }^{[8-19]}$ The first known palladium-catalyzed enantioselective allylic alkylation was introduced by Trost and Strege with moderate enantioselectivities in the presence of chiral 2,3-Oisoproylidene-2,3dihydroxy-1,4-bis(diphenylphosphino)butane (DIOP). ${ }^{[20]}$ Since the initial report, it took many years to develop efficient enantioselective catalysts due to the complex enantiocontrol in allylic substitutions. Later on, different type of nitrogen, phosphorus, $\mathrm{P}, \mathrm{X}(\mathrm{P}, \mathrm{N}-, \mathrm{P}, \mathrm{O}$ - and $P, S-)$ ligands were developed and were utilized in the enantioselective allylic alkylation with successfully. ${ }^{[21-27]}$

The asymmetric transfer hydrogenation (ATH) or reduction of ketones allows the production of a large number of useful chiral alcohols that are ubiquitous in nature and are in great demand for flavors and fragrances, for pharmaceuticals, and for agrochemicals. ${ }^{[28-35]}$ Apart from some procedures, ATH includes some interesting advantages such as using environmentally friendly solvents, low catalyst loading, safe application and volatile byproducts. Consequently, it can be easily applied to industrial processes. Thanks to noteworthy advantages, ATH is a transformation which is upmost significance. Therefore, ATH of ketones has been performed using different transition metals ( $\mathrm{Ru}, \mathrm{Rh}, \mathrm{Fe}, \mathrm{Ir}, \mathrm{Ni}$, Co etc.) in combination with chiral ligands containing coordinating atoms (phosphorous, oxygen, nitrogen and sulfur) by many researchers. ${ }^{[36-45]}$

Recently, we have reported on a set of six chiral modular bisphosphine ligands with dimethoxy backbone for enantioselective catalytic reactions (Figure 1.). ${ }^{[46]}$ They have showed some promising results in the palladium(0)catalyzed enantioselective allylic alkylation reaction $(70 \%$ chemical yield and $43 \%$ ee) and the ruthenium(II)-catalyzed transfer hydrogenation (up to $>99 \%$ conversion). As part of our ongoing interest towards the development of 


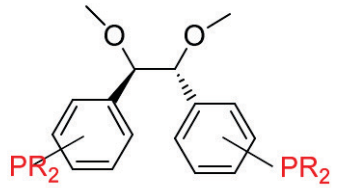

$\mathrm{PR}_{2}=2-\mathrm{PPh}_{2}, 2-\mathrm{PCy}_{2}$

$3-\mathrm{PPh}_{2}, 3-\mathrm{PCy}_{2}$

$4-\mathrm{PPh}_{2}, 4-\mathrm{PCy}_{2}$

Figure 1. Bisphosphine ligands with dimethoxy backbone.

enantioselective catalysts, we have developed a set of six chiral bisphosphine ligands containing a dioxolane ring as backbone. A careful combination of a metal with an appropriate ligand is a key requisite in order to obtain high enantioselective inductions. Taking these data into account, our synthesized bisphosphine ligands allow rapid diversification such as variation of the bulkiness of the $R$ substituents at the backbone and modification of the electronic and steric properties of the chelating phosphorus atoms. These synthesized ligands were tested and compared in the palladium-catalyzed enantioselective allylic alkylation and the ruthenium-catalyzed transfer hydrogenation.

\section{EXPERIMENTAL SECTION}

\section{Materials}

All reagents were purchased and used without purification, unless otherwise noted. Compounds: $(1 R, 2 R)$-1,2-bis(2'-bromophenyl)-ethane-1,2-diol (1R,2R)-1,2-bis(3'-bromophenyl)-ethane-1,2-diol $(1 R, 2 R)$-1,2-bis(4'-bromophenyl)-ethane-1,2-diol 3 $(4 R, 5 R) 4,5$-bis-(2 -bromophenyl)-2,2-dimethyl-1,3-dioxolane 4 and ( $4 R, 5 R)-4,5$-bis-(4 bromophenyl)-2,2-dimethyl1,3-dioxolane 6 were synthesized according to previously described procedures. ${ }^{[47-50]}$ Analytical TLC was performed using Macherey-Nagel SIL G-25 UV254 plates. Flash chromatography was carried out with Rocc silica gel (0.040-0.063 mm). ${ }^{1} \mathrm{H},{ }^{13} \mathrm{C}$ and ${ }^{31} \mathrm{P}$ NMR spectra were recorded on a Varian Mercury $400 \mathrm{MHz}$ spectrometer as indicated, with chemical shifts reported in ppm relative to TMS (for ${ }^{1} \mathrm{H}$ and ${ }^{13} \mathrm{C} \mathrm{NMR}$ ), and relative to $85 \%$ aqueous phosphoric acid (for ${ }^{31} \mathrm{P}$ ), using the residual solvent signal as a standard. ${ }^{13} \mathrm{C}$ NMR spectra were recorded using the attached proton test. IR-spectra were recorded on a PerkinElmer Spectrum 65 FT-IR spectrometer. Analytical chiral HPLC separations were performed on a Shimadzu Prominence LC-20A with DAD detection. GC separations were performed on Shimadzu GC-2010 Plus. Optical rotations were measured with a Rudolph Autopol-I series polarimeter. Mass spectra were an Agilent LC-MS/MS 6460 Triple Quadrupole spectrometer. Elemental analyses were obtained with a LECO Elemental Analyser (CHNS 0932). Melting points were measured with a Thermo Scientific 9200 melting point apparatus.

\section{Synthesis}

\section{(4R,5R)-4,5-BIS-(3 -BROMOPHENYL)-2,2-DIMETHYL-1,3- DIOXOLANE (5)}

A mixture of $(1 R, 2 R)$-1,2-bis(3'-bromophenyl)-ethane-1,2diol 2 (2.5 g, $6.7 \mathrm{mmol}), 2$,2'dimethoxypropane (7.0 g, $67.2 \mathrm{mmol}$ ) and 3 drops of conc. $\mathrm{HCl}$ in a standart Schlenk tube was stirred at room temperature for $16 \mathrm{~h}$. The reaction was monitored by thin layer chromatography using hexane - ethyl acetate $(9: 1)$ as the solvent system. At the end of this period, $10 \mathrm{ml}$ of dichloromethane and 3 drops of triethyl amine were added and the reaction mixture was stirred for another $1 \mathrm{~h}$ at room temperature. The resulting mixture was passed through a short alumina column and the solvent was evaporated under reduced pressure. The crude product was purified by flash chromatography over silica gel with dichloromethane resulting in $2.6 \mathrm{~g}$ (94\%) of pure 5 as a transparent oil. +91.93 ( $c=1, \mathrm{CHCl}_{3}$ ); IR ( $\left.\mathrm{KBr}\right) 3064$ (aromatic $v \mathrm{CH}$ ), 2986 (aliphatic $\vee \mathrm{CH}$ ), 2932 (aliphatic $\vee \mathrm{CH}$ ), 2881 (aliphatic $\vee \mathrm{CH}$ ), 1570 (aromatic v CC), 1473 (aliphatic v CH), 1427, 1374, 1236, 1064 ( $v$ C-O), 870, 784, 693; ${ }^{1} \mathrm{H}$ NMR (400 MHz, $\left.\mathrm{CDCl}_{3}, \mathrm{ppm}\right) \delta: 1.67(6 \mathrm{H}, \mathrm{s}), 4.65(2 \mathrm{H}, \mathrm{s}), 7.04(2 \mathrm{H}, \mathrm{dt}, J=7.7$ $\mathrm{Hz} J=1.3 \mathrm{~Hz}), 7.19(2 \mathrm{H}, \mathrm{d}, J=7.8 \mathrm{~Hz}), 7.44-7.48(4 \mathrm{H}, \mathrm{m}) ;{ }^{13} \mathrm{C}$ NMR $\left(101 \mathrm{MHz}, \mathrm{CDCl}_{3}, \mathrm{ppm}\right) \delta: 27.1\left(\mathrm{CH}_{3}\right), 84.6(\mathrm{CH}), 110.0$ (C), 122.8 (C), $125.5(\mathrm{CH}), 129.5(\mathrm{CH}), 130.0(\mathrm{CH}), 131.6$ $(\mathrm{CH}), 138.7$ (C); $\mathrm{MS}\left(\mathrm{ES}^{+}\right)$: $397.9\left(\left[\mathrm{M}-\mathrm{CH}_{3}+\mathrm{H}\right]^{+}, \mathrm{C}_{16} \mathrm{H}_{14} \mathrm{Br}_{2} \mathrm{O}_{2}\right.$; calc. 397.3); Anal. calc. for $\mathrm{C}_{17} \mathrm{H}_{16} \mathrm{Br}_{2} \mathrm{O}_{2}$ : C 49.55, H 3.91; found: C 49.17, H 3.88 .

\section{(4R,5R)-4,5-BIS(2 -(DIPHENYLPHOSPHINO)PHENYL)-2,2- DIMETHYL-1,3-DIOXOLANE (7) ${ }^{[49]}$}

A mixture of $(4 R, 5 R)-4,5$-bis-(2 -bromophenyl)-2,2dimethyl-1,3-dioxolane 4 ( $0.5 \mathrm{~g}, 1.2 \mathrm{mmol}$ ) and $15 \mathrm{~mL}$ of dry THF were placed under a nitrogen atmosphere in a standard Schlenk tube and cooled to $-78^{\circ} \mathrm{C}$. To this solution was added BuLi $(2.4 \mathrm{ml}, 3.9 \mathrm{mmol})$ at $78^{\circ} \mathrm{C}$ and stirred for $1 \mathrm{~h}$ at that temperature. $\mathrm{Ph}_{2} \mathrm{PCl}(0.5 \mathrm{~mL}, 2.8 \mathrm{mmol})$ was added dropwise to the resulting mixture. After addition was complete, the reaction mixture was stirred for another $1 \mathrm{~h}$ at room temperature. The reaction was monitored by thin layer chromatography using hexane - ethyl acetate $(9: 1)$ as the solvent system. Evaporation in vacuo and purification by flash chromatography over silica gel (hexane / AcOEt, $9: 1$ ) resulted in 7 as a pure white solid (0.5 g; $59 \%$ ). $\mathrm{mp} 71-72{ }^{\circ} \mathrm{C} .=-97,93\left(\mathrm{c}, 1.0, \mathrm{CHCl}_{3}\right) ; \mathrm{IR}(\mathrm{KBr}) 3055$, 
2984, 2921, 1736, 1475, 1434, 1233, 1047, 742, 696; ${ }^{1 \mathrm{H}}$ NMR (400 MHz, $\left.\mathrm{CDCl}_{3}, \mathrm{ppm}\right) \delta: 1.59(\mathrm{~s}, 6 \mathrm{H}), 6.05(\mathrm{~d}, J=5.5$ $\mathrm{Hz}, 2 \mathrm{H}), 6.75(\mathrm{t}, J=7.7 \mathrm{~Hz}, 4 \mathrm{H}), 6.81$ (ddd $J=7.8 \mathrm{~Hz}, J=4.0$ $\mathrm{Hz}, J=1.2 \mathrm{~Hz}, 2 \mathrm{H}), 6.98-7.05(\mathrm{~m}, 6 \mathrm{H}), 7.09-7.16(\mathrm{~m}, 6 \mathrm{H})$, 7.23-7.26 (m, 8H), $7.72(\mathrm{~m}, 2 \mathrm{H}) ;{ }^{13} \mathrm{C} \mathrm{NMR} \mathrm{(101} \mathrm{MHz,} \mathrm{CDCl}_{3}$, ppm) $\delta: 27.3\left(\mathrm{CH}_{3}\right), 81.9(\mathrm{~d}, \mathrm{~J}=28 \mathrm{~Hz}, \mathrm{CH}), 109.1$ (C), 128.0$128.5(\mathrm{~m}, \mathrm{CH}), 129.6(\mathrm{CH}), 133.1(\mathrm{~d}, J=20 \mathrm{~Hz}, \mathrm{CH}), 133.4$ (d, $J=19 \mathrm{~Hz}, \mathrm{CH}), 134.4(\mathrm{CH}), 136.1(\mathrm{~d}, J=16 \mathrm{~Hz}, \mathrm{C}), 136,6(\mathrm{C})$, $137.9(\mathrm{~d}, J=11 \mathrm{~Hz}, \mathrm{C}), 140.3(\mathrm{~d}, J=24.2 \mathrm{~Hz}, \mathrm{C}) ;{ }^{31} \mathrm{P}-\mathrm{NMR}$ : $\left(162 \mathrm{MHz}, \mathrm{CDCl}_{3}, \mathrm{ppm}\right) \delta:-18.27$.

\section{(4R,5R)-4,5-BIS(3 -(DIPHENYLPHOSPHINO)PHENYL)-2,2- DIMETHYL-1,3-DIOXOLANE (8)}

Synthesis of $\mathbf{8}$ was performed by following the procedure for 7 by using $(4 R, 5 R)-4,5$-bis-(3 bromophenyl)-2,2dimethyl-1,3-dioxolane 5 (0.5 g, $1.21 \mathrm{mmol})$, BuLi (2.4 mL, $3.9 \mathrm{mmol})$ and $\mathrm{Ph}_{2} \mathrm{PCl}(0.5 \mathrm{ml}, 2.8 \mathrm{mmol})$. The crude product was purified by silica gel chromatography. The elution was carried out with hexane-ethyl acetate $(9: 1)$. The product was obtained as a white solid. Yield: $0.4 \mathrm{~g} ; 46 \%$. mp 53$55^{\circ} \mathrm{C}$. $+109.93\left(c=1, \mathrm{CHCl}_{3}\right)$; IR ( $\left.\mathrm{KBr}\right) 3054$ (aromatic $v \mathrm{CH}$ ), 2985 (aliphatic $\vee \mathrm{CH}$ ), 2931 (aliphatic $\vee \mathrm{CH}$ ), 2880 (aliphatic $v \mathrm{CH}$ ), 1957, 1736, 1586 (aromatic $v$ CC), 1477 (aliphatic $v$ CH), 1431 ( $v$ P-C), 1374, 1233 ( $v$ P-O), 1064, 823, 742, 697; ${ }^{1} \mathrm{H}$ NMR $\left(400 \mathrm{MHz}, \mathrm{CDCl}_{3}, \mathrm{ppm}\right) \delta: 1.49(6 \mathrm{H}, \mathrm{s}), 4.56(2 \mathrm{H}, \mathrm{s})$, 7.10-7.12 (4H, m), 7.21-7.25 (10H, m), 7.31 (10H, m), 7.42$7.62(4 \mathrm{H}, \mathrm{m}) ;{ }^{13} \mathrm{C} \mathrm{NMR}\left(101 \mathrm{MHz}, \mathrm{CDCl}_{3}, \mathrm{ppm}\right) \delta: 27.0\left(\mathrm{CH}_{3}\right)$, $85.5(\mathrm{CH}), 109.6(\mathrm{C}), 127.1(\mathrm{CH}), 128.7(\mathrm{CH}), 128.5(\mathrm{~d}, \mathrm{~J}=6.6$ $\mathrm{Hz}, \mathrm{CH}), \quad 131.7(\mathrm{CH}), 131.9(\mathrm{CH}), 133.5-133.8(\mathrm{~m}, \mathrm{CH})$, $136.8(\mathrm{~d}, J=6.6 \mathrm{~Hz}, \mathrm{C}), 136.9(\mathrm{~d}, J=4.4 \mathrm{~Hz}, \mathrm{C}), 137.0(\mathrm{~d}, J=$ 3.6 Hz, C), 137.7 (d, J=11.7 Hz, C); ${ }^{31 P-N M R: ~(162 ~ M H z, ~}$ $\left.\mathrm{CDCl}_{3}, \mathrm{ppm}\right) \delta$ : -5.4; $\mathrm{MS}\left(\mathrm{ES}^{+}\right): 623.2\left([\mathrm{M}+\mathrm{H}]^{+}, \mathrm{C}_{41} \mathrm{H}_{36} \mathrm{O}_{2} \mathrm{P}_{2}\right.$; calc. 623.3). Anal. calc. for $\mathrm{C}_{41} \mathrm{H}_{36} \mathrm{O}_{2} \mathrm{P}_{2}$ : C 79.08, H 5.83; found: C 78.84, H 5.92.

\section{(4R,5R)-4,5-BIS(4 -(DIPHENYLPHOSPHINO)PHENYL)-2,2- DIMETHYL-1,3-DIOXOLANE (9)}

Synthesis of 9 was performed by following the procedure for 7 by using $(4 R, 5 R)-4,5$-bis-( 4 bromophenyl)-2,2dimethyl-1,3-dioxolane 5 (0.5 g, $1.2 \mathrm{mmol})$, BuLi (2.4 ml, 3.9 $\mathrm{mmol})$ and $\mathrm{Ph}_{2} \mathrm{PCl}(0.5 \mathrm{ml}, 2.8 \mathrm{mmol})$. The crude product was purified by silica gel chromatography. The elution was carried out with hexane-ethyl acetate (8:2). The product was obtained as a white solid. Yield: $0.5 \mathrm{~g}$; $63 \%$. mp 75$77^{\circ} \mathrm{C} .+175.86\left(c=1, \mathrm{CHCl}_{3}\right) ; \mathrm{IR}(\mathrm{KBr}) 3054$ (aromatic $v \mathrm{CH}$ ), 2983 (aliphatic $v \mathrm{CH}), 2931$ (aliphatic $v \mathrm{CH}), 2885,1432(v$ $\mathrm{P}-\mathrm{C}), 1233$ ( $v \mathrm{P}-\mathrm{O}), 1062,824,744,696 ;{ }^{1} \mathrm{H}$ NMR (400 MHz, $\left.\mathrm{CDCl}_{3}, \mathrm{ppm}\right) \delta: 1.64(6 \mathrm{H}, \mathrm{s}), 4.75(2 \mathrm{H}, \mathrm{s}), 7.20-7.35(24 \mathrm{H}, \mathrm{m})$, 7.49-7.65 (4H, m); $\left.{ }^{13} \mathrm{C} \mathrm{NMR} \mathrm{(101} \mathrm{MHz,} \mathrm{CDCl}_{3}, \mathrm{ppm}\right) \delta: 27.1$ $\left(\mathrm{CH}_{3}\right), 85.0(\mathrm{CH}), 109.6(\mathrm{C}), 126.9(\mathrm{~d}, J=6.6 \mathrm{~Hz}, \mathrm{CH}), 128.6$ (d, J=6.6 Hz, CH), $128.9(\mathrm{CH}), 132.0-132.5(\mathrm{~m})(\mathrm{CH}), 133.9-$ 133.7 (dd, J = $19 \mathrm{~Hz}, J=4.4 \mathrm{~Hz}, \mathrm{CH}), 137.2$ (C), 137.3 (C), 137.4 (C); ${ }^{31} \mathrm{P}-\mathrm{NMR}:\left(162 \mathrm{MHz}^{\mathrm{C}} \mathrm{CDCl}_{3}, \mathrm{ppm}\right) \delta$ : -5.9 ; MS
$\left(\mathrm{ES}^{+}\right)$: $623.2\left([\mathrm{M}+\mathrm{H}]^{+}, \mathrm{C}_{41} \mathrm{H}_{36} \mathrm{O}_{2} \mathrm{P}_{2}\right.$; calc. 623.3); Anal. calc. for $\mathrm{C}_{41} \mathrm{H}_{36} \mathrm{O}_{2} \mathrm{P}_{2}$ : C 79.08, H 5.83; found: C 78.82, H 6.15.

\section{(4R,5R)-4,5-BIS(2 -(DICYCLOHEXYLPHOSPHINO)PHENYL)-}

\section{2,2- DIMETHYL-1,3-DIOXOLANE (10)}

Synthesis of $\mathbf{1 0}$ was performed by following the procedure for 7 by using $(4 R, 5 R)-4,5$-bis-(2 bromophenyl)-2,2dimethyl-1,3-dioxolane 4 (0.5 g, $1.2 \mathrm{mmol})$, BuLi (2.4 mL, $3.9 \mathrm{mmol})$ and $\mathrm{Cy}_{2} \mathrm{PCl}(0.6 \mathrm{ml}, 2.8 \mathrm{mmol})$. The crude product was purified by silica gel chromatography. The elution was carried out with hexane-ethyl acetate $(9: 1)$. The product was obtained as oil. Yield: $0.5 \mathrm{~g} ; 65 \% .7 .99\left(c=1, \mathrm{CHCl}_{3}\right)$; IR $(\mathrm{KBr}) 3053$ (aromatic $v \mathrm{CH}), 2982$ (aliphatic $v \mathrm{CH}), 2924$ (aliphatic $v \mathrm{CH}), 1446(v \mathrm{P}-\mathrm{C}), 1372,1231(v \mathrm{P}-\mathrm{O}), 1168$, $1048,893,697 ;{ }^{1} \mathrm{H}$ NMR $\left(400 \mathrm{MHz}, \mathrm{CDCl}_{3}, \mathrm{ppm}\right) \delta$ : 0.93$1.73(50 \mathrm{H}, \mathrm{m}), 4.75(2 \mathrm{H}, \mathrm{s}), 7.21-7.31(2 \mathrm{H}, \mathrm{m}), 7.50(2 \mathrm{H}, \mathrm{m})$, $7.74(2 \mathrm{H}, \mathrm{m}), 7.93(2 \mathrm{H}, \mathrm{m}) ;{ }^{13} \mathrm{C} \mathrm{NMR}\left(101 \mathrm{MHz}, \mathrm{CDCl}_{3}, \mathrm{ppm}\right)$ $\delta: 25.3-27.8(\mathrm{~m})\left(\mathrm{CH}_{3}, \mathrm{CH}_{2}\right), 29.7\left(\mathrm{CH}_{2}\right), 32.8(\mathrm{CH}), 85.5(\mathrm{CH})$, $109.4(\mathrm{C}), 126.0(\mathrm{C}), 126.7(\mathrm{CH}), 127.4(\mathrm{CH}), 128.2(\mathrm{CH})$, 128.4 (CH), 136.8 (C); ${ }^{31} \mathrm{P}-\mathrm{NMR}:\left(162 \mathrm{MHz}, \mathrm{CDCl}_{3}, \mathrm{ppm}\right) \delta$ : -15.7; $\mathrm{MS}\left(\mathrm{ES}^{+}\right)$: $647.4\left([\mathrm{M}+\mathrm{H}]^{+}, \mathrm{C}_{41} \mathrm{H}_{60} \mathrm{O}_{2} \mathrm{P}_{2}\right.$; calc. 647.5); Anal. calc. for $\mathrm{C}_{41} \mathrm{H}_{60} \mathrm{O}_{2} \mathrm{P}_{2}: \mathrm{C} 76.13, \mathrm{H}$ 9.35; found: C 75.82, H 9.05 .

\section{(4R,5R)-4,5-BIS(3 -(DICYCLOHEXYLPHOSPHINO)PHENYL)- 2,2- DIMETHYL-1,3-DIOXOLANE (11)}

Synthesis of $\mathbf{1 1}$ was performed by following the procedure for 7 by using (4R,5R)-4,5-bis-(3 bromophenyl)-2,2dimethyl-1,3-dioxolane 5 (0.5 g, $1.2 \mathrm{mmol})$, BuLi $(2.4 \mathrm{~mL}$, $3.9 \mathrm{mmol})$ and $\mathrm{Cy}_{2} \mathrm{PCl}(0.6 \mathrm{~mL}, 2.8 \mathrm{mmol})$. The crude product was purified by silica gel chromatography. The elution was carried out with hexane-ethyl acetate $(9: 1)$. The product was obtained as oil. Yield: $0.7 \mathrm{~g} ; 84 \%$. +37.97 $\left(c=1, \mathrm{CHCl}_{3}\right.$ ); IR ( $\left.\mathrm{KBr}\right) 3053$ (aromatic $v \mathrm{CH}$ ), 2928 (aliphatic $v \mathrm{CH}), 2852$ (aliphatic $v \mathrm{CH}$ ), $1448(v \mathrm{P}-\mathrm{C}), 1373,1229$ ( $v \mathrm{P}-$ O), $1170,1061,1110,702 ;{ }^{1} \mathrm{H} \mathrm{NMR}\left(400 \mathrm{MHz}, \mathrm{CDCl}_{3}, \mathrm{ppm}\right)$ $\delta: 1.13-2.04(5 \mathrm{OH}, \mathrm{m}), 4.76(2 \mathrm{H}, \mathrm{s}), 7.30(2 \mathrm{H}, \mathrm{d}, J=6.8 \mathrm{~Hz})$, $7.40(2 \mathrm{H}, \mathrm{dt}, J=7.8 \mathrm{~Hz}, J=1.8 \mathrm{~Hz}), 7.56(2 \mathrm{H}, \mathrm{d}, J=9.5 \mathrm{~Hz})$ $7.30(2 \mathrm{H}, \mathrm{d}, J=6.8 \mathrm{~Hz}), 7.30(2 \mathrm{H}, \mathrm{d}, J=8.2 \mathrm{~Hz}) ;{ }^{13} \mathrm{C} \mathrm{NMR}(101$ $\left.\mathrm{MHz}, \mathrm{CDCl}_{3}, \mathrm{ppm}\right) \delta: 25.9\left(\mathrm{CH}_{2}\right), 26.2(\mathrm{dd} J=10.2 \mathrm{~Hz}, J=2.9$ $\left.\mathrm{Hz}, \mathrm{CH}_{2}\right) 26.2\left(\mathrm{~d} J=4.4 \mathrm{~Hz}, \mathrm{CH}_{2}\right), 26.7\left(\mathrm{~d} J=11.7 \mathrm{~Hz}, \mathrm{CH}_{2}\right.$ ), $27.1\left(\mathrm{CH}_{3}\right), 31.3\left(\mathrm{dd}, J=33 \mathrm{~Hz}, J=4.5 \mathrm{~Hz}, \mathrm{CH}_{2}\right) 85.4(\mathrm{CH})$, $110.2(\mathrm{C}), 126.4$ (d, J = 46 Hz, C), $128.6(\mathrm{~d}, J=9.5 \mathrm{~Hz}, \mathrm{CH}$ ), $129.3(\mathrm{~d}, J=2.2 \mathrm{~Hz}, \mathrm{CH}), 131.6$ (d, J = 7.3 Hz, CH), 133.6 (d, $J=7.3 \mathrm{~Hz}, \mathrm{CH}), 136.9$ (d, $J=8.8 \mathrm{~Hz}, \mathrm{C})$; ${ }^{31} \mathrm{P}-\mathrm{NMR}:(162 \mathrm{MHz}$, $\left.\mathrm{CDCl}_{3}, \mathrm{ppm}\right) \delta$ : 3.1; MS $\left(\mathrm{ES}^{+}\right): 647.4\left([\mathrm{M}+\mathrm{H}]^{+}, \mathrm{C}_{41} \mathrm{H}_{60} \mathrm{O}_{2} \mathrm{P}_{2}\right.$ : calc. 647.5); Anal. calc. for $\mathrm{C}_{41} \mathrm{H}_{60} \mathrm{O}_{2} \mathrm{P}_{2}$ : C 76.13, H 9.35; found: C 76.64, H 9.61.

\section{(4R,5R)-4,5-BIS(4 -(DICYCLOHEXYLPHOSPHINO)PHENYL)- 2,2- DIMETHYL-1,3-DIOXOLANE (12)}

Synthesis of 12 was performed by following the procedure for 7 by using $(4 R, 5 R)-4,5$-bis-( 4 bromophenyl)-2,2- 
dimethyl-1,3-dioxolane 6 (0.5 g, $1.2 \mathrm{mmol})$, BuLi $(2.4 \mathrm{~mL}$, $3.9 \mathrm{mmol})$ and $\mathrm{Cy}_{2} \mathrm{PCl}(0.6 \mathrm{~mL}, 2.8 \mathrm{mmol})$. The crude product was purified by silica gel chromatography. The elution was carried out with hexane-ethyl acetate $(9: 1)$. The product was obtained as oil. Yield: $0.4 \mathrm{~g} ; 48 \%$. +97.92 $\left(c=1, \mathrm{CHCl}_{3}\right) ; \mathrm{IR}(\mathrm{KBr}) 3053$ (aromatic $\left.v \mathrm{CH}\right), 2924$ (aliphatic $v \mathrm{CH}), 2852$ (aliphatic $v \mathrm{CH}), 1446(v \mathrm{P}-\mathrm{C}), 1373,1232$ ( $v$ P-

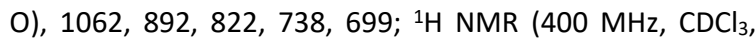
ppm) $\delta: 0.93-1.84(50 \mathrm{H}, \mathrm{m}), 4.78(2 \mathrm{H}, \mathrm{s}), 7.14(4 \mathrm{H}, \mathrm{d}, J=8$ $\mathrm{Hz}), 7.42(4 \mathrm{H}, \mathrm{m}) ;{ }^{13} \mathrm{C} \mathrm{NMR}\left(101 \mathrm{MHz}, \mathrm{CDCl}_{3}, \mathrm{ppm}\right) \delta: 25.9$ $\left(\mathrm{CH}_{2}\right), 26.3\left(\mathrm{dd} \mathrm{J}=8.0 \mathrm{~Hz}, J=2.2 \mathrm{~Hz}, \mathrm{CH}_{2}\right) 26.5-26.8\left(\mathrm{~m}, \mathrm{CH}_{2}\right)$, $27.1\left(\mathrm{CH}_{3}\right), 31.0-31.5\left(\mathrm{~m}, \mathrm{CH}_{2}\right) 84.7(\mathrm{CH}), 110.1(\mathrm{C}), 126.3$, $125.8(\mathrm{~d}, J=48 \mathrm{~Hz}, \mathrm{C}), 133.6(\mathrm{~d}, J=9.5 \mathrm{~Hz}, \mathrm{CH}), 133.7(\mathrm{~d}, J=$ $7.3 \mathrm{~Hz}, \mathrm{CH}$ ), 139.8 (d, J=2.2 Hz, C) ${ }^{31} \mathrm{P}-\mathrm{NMR}$ : (162 MHz, $\left.\mathrm{CDCl}_{3}, \mathrm{ppm}\right) \delta$ : 2.4; $\mathrm{MS}\left(\mathrm{ES}^{+}\right): 647.4\left([\mathrm{M}+\mathrm{H}]^{+}, \mathrm{C}_{41} \mathrm{H}_{60} \mathrm{O}_{2} \mathrm{P}_{2}\right.$ : calc. 647.5); Anal. calc. for $\mathrm{C}_{41} \mathrm{H}_{60} \mathrm{O}_{2} \mathrm{P}_{2}$ : C 76.13, H 9.35; found: C 48.41, H 9.33.

\section{GENERAL PROCEDURE FOR THE TRANSFER HYDROGENATION OF AROMATIC KETONES}

A mixture of $\left[\mathrm{Ru}(p \text {-cymene }) \mathrm{Cl}_{2}\right]_{2}(0.004 \mathrm{mmol})$ and corresponding chiral bisphosphine ligand (7-12) $(0.004 \mathrm{mmol})$ in ${ }^{\mathrm{P}} \mathrm{POH}(7 \mathrm{~mL})$ were placed under a nitrogen atmosphere in a standard Schlenk tube. The reaction mixture was heated and stirred under nitrogen at $82^{\circ} \mathrm{C}$ for $2 \mathrm{~h}$. After cooling to room temperature, the aromatic ketone ( $1 \mathrm{mmol}$ ) was added to this mixture and the solution was then heated to $82{ }^{\circ} \mathrm{C}$. To initiate the reaction, the solution of $t$-BuOK $(0.05 \mathrm{mmol})$ in ${ }^{\mathrm{P} r O H}$ was added to the stirring reaction mixture. To monitor the conversions of ketones to corresponding secondary alcohols, a small volume of reaction mixture was taken from Schlenk tube via micro syringe and diluted with ${ }^{\mathrm{P}} \mathrm{POH}$, and then passed from microfilter. The conversion and enantiomeric excess were monitored by GC using Agilent HP-Chiral 20B column.

\section{GENERAL PROCEDURE FOR PD-CATALYZED} ENANTIOSELECTIVE ALLYLIC ALKYLATION

Corresponding bisphosphine ligand (7-12) $(0.05 \mathrm{mmol})$ and $\left[\mathrm{Pd}\left(\eta^{3}-\mathrm{C}_{3} \mathrm{H}_{5}\right) \mathrm{Cl}\right]_{2}(0.02 \mathrm{mmol})$ were dissolved in degassed $\mathrm{CH}_{2} \mathrm{Cl}_{2}$ or THF under argon atmosphere using Schlenk techniques. The reaction mixture was stirred for $1 \mathrm{~h}$ at $50{ }^{\circ} \mathrm{C}$ and cooled to room temperature. Then (E)-1,3-diphenylallyl acetate (13) (1 mmol) was added and stirred at room temperature for $30 \mathrm{~min}$. Finally, a solution of BSA ( $3 \mathrm{mmol}$ ), ACOLi or ACOK $(0.1 \mathrm{mmol})$ and dimethylmalonate or acetylacetone $(3 \mathrm{mmol})$ was added to the mixture. The reaction mixture was stirred for $16 \mathrm{~h}$ at room temperature. Next, diethylether was added, washed with saturated $\mathrm{NH}_{4} \mathrm{Cl}$, dried on $\mathrm{MgSO}_{4}$ and concentrated in vacuo. The crude product was purified by flash chromatography on silica gel (Hexane / AcOEt, 90 / 10) to afford the target compound. All adducts were fully characterized by comparison of their spectral data with those reported in the literature. The absolute configurations were assigned via correlation of their optical rotation with literature values. ${ }^{[51-54]}$ The enantiomeric excess was determined by chiral HPLC analysis.

\section{RESULTS AND DISCUSSION}

The synthetic routes towards the enantiomerically pure $C_{2-}$ symmetric bisphosphine ligands with a dioxolane backbone started with the corresponding bromo-substituted diols 13 which were previously described by our group (Scheme 1). ${ }^{[47,48]}$ Chiral bromo-substituted diols are the key structures in our synthesis of bisphosphine ligands 7-12.

Bisphosphine ligand $\mathbf{7}$ has been synthesized by Brunner. ${ }^{[49]}$ By using this literature procedure, the reaction of chiral bromo-substituted diol 1 with 2,2-dimethoxypropane afforded $(4 R, 5 R)-4,5$-bis-(3 -bromophenyl)-2,2-dimethyl-1,3dioxolane 4 with high chemical yield $(90 \%)$. The last step for desired bisphosphine 7 was the reaction of the compound $\mathbf{4}$ with chlorodiphenylphosphine in the presence of a base. Thus, bisphosphine ligand $\mathbf{7}$ was synthesized in two steps in good overall yields. Novel bisphosphine ligands $\mathbf{8}$ and $\mathbf{9}$ were synthesized from the corresponding compounds according to the same method as the synthesis of ligand 7. Novel bisphosphine ligands $\mathbf{1 0}$ 12 were synthesized from the corresponding compounds 4-6 by the treatment of chlorodicyclohexylphosphine in the presence of a base. Although bisphosphine ligands

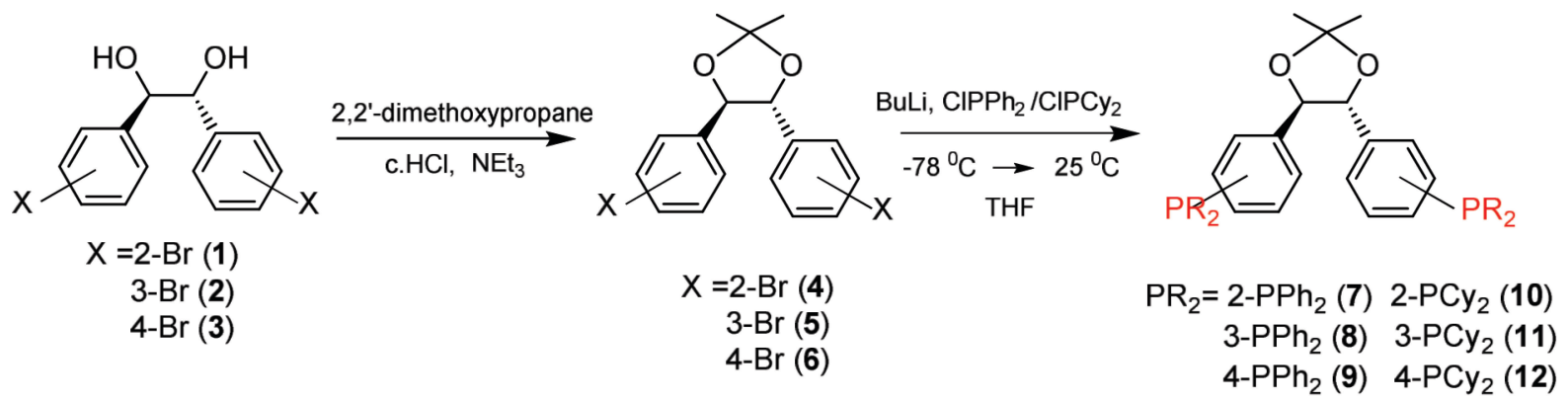

Scheme 1 . Synthesis of $C_{2}$-symmetric bisphosphine ligands 7-12. 
10-12 are not stable enough in air at room temperature, it should be noted that bisphosphine ligands 7-9 are stable for a few days.

The palladium-catalyzed enantioselective allylic alkylation was chosen as the first catalytic test reaction in order to determine the efficiency of the synthesized bisphosphine ligands. Although the mechanism as well as the active species equilibria are known, the performance of the catalytic system depends on the fine tuning of factors such as type of substrate, nucleophile nature, reaction medium, catalytic precursor and type of ligand used. The chiral model formed by Pd-ligand fragment is believed to be related to the P-Pd-P bite angle. ${ }^{[23,55-57]}$ According to all literature data, we tested all bisphosphine ligands 7-12 in the allylic alkylation of rac-1,3-diphenyl-3-acetoxyprop-1ene 13 with different nucleophiles (3 equiv) such as dimethylmalonate (DMM) and acetylacetone (Acac) in the presence of $\mathrm{N}$-Obis(trimethylsilyl) acetamide (BSA) (3 equiv) and $0.1 \mathrm{~mol} \% \mathrm{BSA}$ activator (AcOLi or AcOK) in different solvents (dichlorometane or tetrahydrofurane) (Table 1).

Despite the poor enantioselectivity, bisphosphine 7 catalyzed the reaction with quantitative yield in the presence of DMM with AcOLi in dichloromethane (Table 1, entry 1). When we used AcOK as a BSA activator, a slightly lower conversion was observed but no enantioinduction was obtained (Table 1, entry 2). Changing the solvent as tetrahydrofurane decreased the conversion in the presence of both BSA activator (ACOLi or ACOK) (Table 1, entries 3 and 4). However, obtaining moderate enantioselectivity with AcOK was noteworthy. The use of acetylacetone as a nucleophile and ACOK as a BSA-activator afforded the corresponding adduct with excellent yield but poor enantioselectivity (Table 1, entry 5). Bisphosphine 8 showed good reactivity but disappointed enantioselectivities in dichloromethane with both AcOLi and AcOK (Table 1 , entries 6 and 7). Poor results were obtained in tetrahydrofurane (Table 1, entries 8 and 9). Changing the nucleophile as acetylacetone also gave unsatisfactory outcomes (Table 1, entry 5). With bisphosphine ligand $\mathbf{9}$, we obtained moderate to good chemical yields but racemic mixtures in all conditions (Table 1, entries 11-14). Similarly, the use of acetylacetone resulted in high activity and almost racemic mixture (Table 1 , entry 15 ). Among the phenyl-substituted bisphosphine ligands, ligand $\mathbf{7}$ gave the maximum enantioinduction with $53 \%$. When it came to cyclohexylsubstituted biphosphines, ligand 10 showed satisfactory results in dichloromethane using with both AcOLi and ACOK respectively ( $43 \%$ ee, $62 \%$ yield and $53 \%$ ee, $98 \%$ yield, Table 1, entries 16 and 17). When the reaction was performed at $0{ }^{\circ} \mathrm{C}$, we observed sharp decrease conversion and a slighltly lower enantioselectivity (60\% ee, $40 \%$ yield, Table 1, entry 18). In sharp contrast, poor results were observed when we changed the solvent as tetrahydrofurane (Table 1, entries 19 and 20). Changing the nucleophile as acetylacetone resulted in moderate enantioselectivity but poor activity (Table 1, entry 21). Performing the reaction with bisphosphine ligand $\mathbf{1 1}$, we observed in all cases poor enantioselectivity and poor to excellent conversion (Table 1, entries 22-26). We determined poor results under the catalysis of bisphosphine ligand $\mathbf{1 2}$ except chemical yields of the reaction treating with AcOK (Table 1, entries 27-31).

Ortho-substituted phosphines catalyzed the alkylation reaction with highest enantioselectivity and conversion among the all ligands. However, orthosubstituted dicyclohexylphosphine ligand $\mathbf{1 0}$ showed higher enantioinduction and conversion than orthosubstituted diphenylphosphine ligand $\mathbf{7}$ in same reaction conditions. Although metasubstituted phosphines $\mathbf{8}$ and $\mathbf{1 1}$ gave some catalytic activity, para-substituted ones 9 and 12 showed almost racemic.

Bisphosphine ligands 7-12 were further tested in the ruthenium-catalyzed transfer hydrogenation of ketones. This type of reaction is one of the mild methodologies for obtaining secondary alcohols which are important building blocks in the synthesis of many biologically and optically active compounds. ${ }^{[58-60]}$ Initial tests were carried out in order to determine efficient reaction parameters such as amount of base, type of base and substrate/catalyst ratio using acetophenone as a substrate in refluxing ${ }^{\mathrm{PrOH}}$ (Table 2).

According to the method, chiral bisphosphine ligand and $\left[\mathrm{Ru}(p \text {-cymene }) \mathrm{Cl}_{2}\right]_{2}$ were dissolved in $\mathrm{PrOH}$ and heated to reflux for $2 \mathrm{~h}$. Ketone and base were added to the reaction mixture after cooling to room temperature. Adding all reagents, reaction was heated to reflux for $24 \mathrm{~h}$. To find efficient reaction conditions, we investigated catalytic activities of all bisphosphine ligands in the presence of $\mathrm{NaOH}(0.05 \mathrm{mmol})$ with a substrate / catalyst (250 / 1) ratio. We determined excellent conversions (Table 2, entries 1-6). Unfortunately, no enantioinduction was noted, which might be attributed to the chiral centers are remoteness to the monohapto P-coordinated ruthenium complexes. ${ }^{[46,61]}$ Bisphosphine ligand $\mathbf{8}$ gave a slightly higher conversion among the all ligands (Table 2 , entry 2). Next, we examined the role of the base under the catalysis of bisphosphine ligand 8. Therefore, $\mathrm{KOH}$ and ${ }^{t}$ BuOK were applied respectively (> $99 \%$ and $94 \%$, Table 2, entries 7 and 8). $\mathrm{KOH}$ was chosen as a base for the catalytic reaction. After determining the appropriate base, it comes to find the best concentration of the base. Thus, we studied different amounts of $\mathrm{KOH}$ concentration. Decreasing the concentration of the base gave low conversion (Table 2, entry 9). In contrast, high conversions were obtained using with high concentration of $\mathrm{KOH}$ (Table 2, entries 10 and 11). The best conversion was obtained in the presence of 
Table 1. $P d$-catalyzed enantioselective allylic alkylation of 13 with dimethylmalonate and acetylacetone in the presence of using bisphosphine ligands 7-12.

\begin{tabular}{|c|c|c|c|c|c|c|}
\hline Entry & Ligand & BSA Activator & Nucleophile & Solvent & Yield / \%(a) & ee $/ \%^{(b, c)}$ \\
\hline 1 & 7 & LiOAc & DMM & Dichloromethane & 99 & $15(S)$ \\
\hline 2 & 7 & KOAC & DMM & Dichloromethane & 93 & $\mathrm{rac}$ \\
\hline 3 & 7 & LiOAC & DMM & Tetrahydrofurane & 42 & $8(R)$ \\
\hline 4 & 7 & KOAC & DMM & Tetrahydrofurane & 46 & $53(R)$ \\
\hline 5 & 7 & KOAC & Acac & Dichloromethane & 99 & $5(S)$ \\
\hline 6 & 8 & LiOAC & DMM & Dichloromethane & 68 & $22(R)$ \\
\hline 7 & 8 & KOAC & DMM & Dichloromethane & 95 & $30(R)$ \\
\hline 8 & 8 & LiOAC & DMM & Tetrahydrofurane & 5 & $16(R)$ \\
\hline 9 & 8 & KOAC & DMM & Tetrahydrofurane & 2 & $30(R)$ \\
\hline 10 & 8 & KOAC & Acac & Dichloromethane & 28 & $21(R)$ \\
\hline 11 & 9 & LIOAC & DMM & Dichloromethane & 97 & rac \\
\hline 12 & 9 & KOAC & DMM & Dichloromethane & 83 & $6(S)$ \\
\hline 13 & 9 & LiOAc & DMM & Tetrahydrofurane & 62 & rac \\
\hline 14 & 9 & KOAC & DMM & Tetrahydrofurane & 43 & $4(S)$ \\
\hline 15 & 9 & KOAC & Acac & Dichloromethane & 99 & $4(S)$ \\
\hline 16 & 10 & LIOAC & DMM & Dichloromethane & 62 & $43(R)$ \\
\hline 17 & 10 & KOAC & DMM & Dichloromethane & 98 & $63(R)$ \\
\hline $18^{d}$ & 10 & KOAC & DMM & Dichloromethane & 40 & $60(R)$ \\
\hline 19 & 10 & LiOAC & DMM & Tetrahydrofurane & 2 & $29(R)$ \\
\hline 20 & 10 & KOAC & DMM & Tetrahydrofurane & 10 & $13(R)$ \\
\hline 21 & 10 & KOAC & Acac & Dichloromethane & 7 & $44(R)$ \\
\hline 22 & 11 & LiOAC & DMM & Dichloromethane & 7 & rac \\
\hline 23 & 11 & KOAC & DMM & Dichloromethane & 82 & $8(R)$ \\
\hline 24 & 11 & LiOAC & DMM & Tetrahydrofurane & 4 & $18(S)$ \\
\hline 25 & 11 & KOAC & DMM & Tetrahydrofurane & 98 & $6(R)$ \\
\hline 26 & 11 & KOAC & Acac & Dichloromethane & 17 & $16(S)$ \\
\hline 27 & 12 & LiOAC & DMM & Dichloromethane & 5 & $7(S)$ \\
\hline 28 & 12 & KOAC & DMM & Dichloromethane & 95 & $20(S)$ \\
\hline 29 & 12 & LIOAC & DMM & Tetrahydrofurane & 8 & rac \\
\hline 30 & 12 & KOAC & DMM & Tetrahydrofurane & 93 & rac \\
\hline 31 & 12 & KOAC & Acac & Dichloromethane & 25 & $8(S)$ \\
\hline
\end{tabular}

(a) Yield of isolated product.

(b) Determined by HPLC analysis with a chiral stationary phase (Chiralcel OD-H).

(c) The absolute configuration was assigned by the sign of the optical rotation.

(d) Reaction was performed at $0^{\circ} \mathrm{C}$. 
$0.05 \mathrm{mmol}$ of $\mathrm{KOH}$ which was quite good concentration for the catalytic reaction. Extended study was applied in order to determine the best substrate/catalyst ratio. When we performed the reaction with 1000 / 1 and 500 / 1 (substrate / catalyst) ratio in same condition, unsatisfactory results were obtained respectively (Table 2 , entries 12 and 13 ). Increasing the substrate / catalyst ratio as 125 / 1 and 100 / 1 resulted with higher conversions (Table 2, entries 14 and 15). Performing the control experiments showed that the base, the precatalyst and the ligand were required for the catalysis (Table 2, entries 16-18). Among the all experiments we studied, the appropriate condition was designated as 250 / 1 substrate / catalyst ratio and $0.05 \mathrm{mmol} \mathrm{KOH}$. According to determined parameters, a series of ketones were explored in ATH reaction (Table 3 ).

In general excellent conversions ranging between $94 \%$ and $>99 \%$ were observed in the reduction of acetophenone derivatives (Table 3 , entries 2-10) except $p$ methoxy-substituted acetophenone (Table 3, entry 1, $78 \%$ ).

\section{CONCLUSION}

In summary, we have synthesized five novel and one known $C_{2}$-symmetric bisphosphine ligands with a dioxolane backbone. All bisphosphine ligands 7-12 were synthesized with good yields in a straightforward manner. Their effectiveness was illustrated in palladiumcatalyzed enantioselective allylic alkylation and ruthenium-catalyzed transfer hydrogenation. The best catalytic results were obtained with ortho-substituted bisphosphine ligands 7 and $\mathbf{1 0}$ in the enantioselective allylic alkylation of rac-1,3diphenyl-3-acetoxyprop-1-ene in the presence of DMM as nucleophile with KOAc. Chiral centers are connexion to the metal center and, therefore they directly influence the stereochemical outcome of the enantioselective reaction. When it came to the steric properties of the chelating atoms, making the ligand electron-rich led to higher enantioselectivity and conversion, as shown in the case of cyclohexyl-substituted bisphosphine 10 (63\% ee, $98 \%$

Table 2. Reaction optimization for transfer hydrogenation of acetophenone.

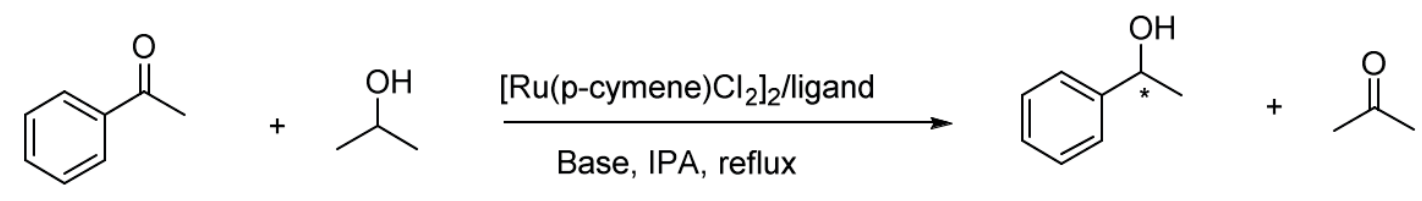

\begin{tabular}{|c|c|c|c|c|c|c|}
\hline Entry & $\mathrm{S} / \mathrm{C}$ & Ligand & Base & Base / mmol & Time / h & ee $/ \%^{(b, c)}$ \\
\hline 1 & $250 / 1$ & 7 & $\mathrm{NaOH}$ & 0.05 & 24 & 96 \\
\hline 2 & $250 / 1$ & 8 & $\mathrm{NaOH}$ & 0.05 & 24 & 98 \\
\hline 3 & $250 / 1$ & 9 & $\mathrm{NaOH}$ & 0.05 & 24 & 97 \\
\hline 4 & $250 / 1$ & 10 & $\mathrm{NaOH}$ & 0.05 & 24 & 32 \\
\hline 5 & $250 / 1$ & 11 & $\mathrm{NaOH}$ & 0.05 & 24 & 95 \\
\hline 6 & $250 / 1$ & 12 & $\mathrm{NaOH}$ & 0.05 & 24 & 94 \\
\hline 7 & $250 / 1$ & 8 & $\mathrm{KOH}$ & 0.05 & 24 & $>99$ \\
\hline 8 & $250 / 1$ & 8 & $t$-BuOK & 0.05 & 24 & 94 \\
\hline 9 & $250 / 1$ & 8 & $\mathrm{KOH}$ & 0.025 & 24 & 68 \\
\hline 10 & $250 / 1$ & 8 & $\mathrm{KOH}$ & 0.1 & 24 & 97 \\
\hline 11 & $250 / 1$ & 8 & $\mathrm{KOH}$ & 0.5 & 24 & 98 \\
\hline 12 & $1000 / 1$ & 8 & $\mathrm{KOH}$ & 0.05 & 24 & 7 \\
\hline 13 & $500 / 1$ & 8 & $\mathrm{KOH}$ & 0.05 & 24 & 13 \\
\hline 14 & $125 / 1$ & 8 & $\mathrm{KOH}$ & 0.05 & 24 & 99 \\
\hline 15 & $100 / 1$ & 8 & $\mathrm{KOH}$ & 0.05 & 24 & 97 \\
\hline 16 & $250 / 1$ & 8 & - & - & 24 & 5 \\
\hline 17 & $250 / 1$ & - & $\mathrm{KOH}$ & 0.05 & 24 & 50 \\
\hline $18^{(\mathrm{c})}$ & $250 / 1$ & 8 & $\mathrm{KOH}$ & 0.05 & 24 & 10 \\
\hline
\end{tabular}

(a) Determined by GC (HP-Chiral-20B).

(b) $\mathrm{PA}(7 \mathrm{~mL}), 82^{\circ} \mathrm{C}$. 
Table 3. Ru-catalyzed asymmetric transfer hydrogenation of ketones with $C_{2}$-symmetric bisphosphine ligand 8 .

\begin{tabular}{|c|c|c|c|c|c|c|c|c|c|}
\hline Entry & Substrate & $\mathrm{S} / \mathrm{C}$ & $\begin{array}{c}\text { Time } \\
{[\mathrm{h}]}\end{array}$ & $\begin{array}{c}\text { Conversion } \\
{[\%]^{[a, b]}}\end{array}$ & Entry & Substrate & $\mathrm{S} / \mathrm{C}$ & $\begin{array}{c}\text { Time } \\
{[\mathrm{h}]}\end{array}$ & $\begin{array}{c}\text { Conversion } \\
{[\%]^{\mathrm{a}, \mathrm{b}}}\end{array}$ \\
\hline 1 & & $250 / 1$ & 24 & 78 & 5 & & $250 / 1$ & 24 & $>99$ \\
\hline 2 & & $250 / 1$ & 24 & 97 & 6 & & $250 / 1$ & 24 & 94 \\
\hline 3 & & $250 / 1$ & 24 & 98 & 7 & & $250 / 1$ & 24 & 94 \\
\hline 4 & & $250 / 1$ & 24 & 96 & 8 & & $250 / 1$ & 24 & $>99$ \\
\hline
\end{tabular}

${ }^{\mathrm{a}}$ Determined by GC (HP-Chiral-20B).

${ }^{\mathrm{b}} \operatorname{IPA}(7 \mathrm{ml}), 82^{\circ} \mathrm{C}$.

chemical yield) than phenylsubstituted bisphosphine 7 ( $53 \%$ ee, $46 \%$ chemical yield). Remarkably, by using all bisphosphine ligands excellent conversion but no enantioinduction were determined. Phenylsubstituted bisphosphine ligand $\mathbf{8}$ showed excellent conversion (up to $>99 \%$ ) in the reduction of acetophenone derivatives.

Acknowledgment. This study was supported by the Scientific \& Technological Research Council of Turkey (TUBITAK) (Project No: KBAG-114Z752).

\section{REFERENCES}

[1] Z. Lu, S. Ma, Angew. Chem. Int. Ed. 2008, 47, 258.

[2] B. M. Trost, M. L. Crawley, Chem. Rev. 2003, 103, 2921.

[3] J. Kraft, K. Mill, T. Ziegler, Molecules 2016, 21, 12, 1704.

[4] T. Ozaki, Y. Kobayashi, Synlett 2016, 27, 611.

[5] T. Rovis, New Frontiers in Asymmetric Catalysis, (Eds. K. Mikami, M. Lautens), WileyVCH, Weinheim, 2007.

[6] D. Šepac, M. Roje, Z. Hameršak, V. Šunji , Croat. Chem. Acta 2003,76, 235.

[7] J. Tsuji, 'Transition Metal Reagents and Catalysts: Innovations in Organic Synthesis', Wiley, Chichester, 2000.

[8] G. Helmchen, A. Pfaltz, Acc. Chem. Res. 2000, 33, 336.
[9] T. B. Wright, P. A. Evans, J. Am. Chem. Soc. 2016, 138, 15303.

[10] X. Hu, H. Dai, H. Chen, J. Wang, C. Bai, Z. Zheng, Tetrahedron Asymmetry 2002, 13, 1687.

[11] J. C. Anderson, J. Osborme, Tetrahedron Asymmetry 2005, 16, 931.

[12] K. Zhang, Q. Peng, X. L. Hou, Y. D. Wu, Angew. Chem. Int. Ed. 2008, 47, 1741.

[13] P. Trillo, I. M. Pastor, Adv. Synth.\& Catal. 2016, 358, 2929.

[14] H. Yuan, Z. Zhou, J. Xiao, L. Liang, L. Dai, Tetrahedron Asymmetry 2010, 21, 1874.

[15] J. Kraft, M. Golkowski, T. Ziegler, Beilstein J. Org. Chem. 2016, 12, 166.

[16] Y. Liu, Z. Cao, H. Du, J. Org. Chem. 2012, 77, 4479.

[17] J. Tydlitat, F. Bures, Z. Ruzickova, Helv. Chim. Acta. 2015, 98, 1351.

[18] D. S. Clyne, Y. C. Mermet-Bouvier, N. Nomura, T. V. RajanBabu, J. Org. Chem. 1999, 64, 7601.

[19] R. K. Sharma, M. Nethaji, A. G. Samuelson, Tetrahedron Asymmetry 2008, 19, 655.

[20] B. M. Trost, P. E. Strege, J. Am. Chem. Soc. 1977, 99, 1649.

[21] Z. Chen, Q. Jiang, G. Zhu, D. Xiao, P. Cao, C. Guo, G. X. J. Zhan,. J. Org. Chem. 1997, 62, 4521.

[22] Y. Gök, H. Z. Gök, Helv. Chim. Acta. 2015, 98, 490.

[23] Y. Gök, T. Noel, J. Van der Eycken, Tetrahedron Asymmetry 2010, 21, 2275. 
[24] X. Jibao, Z. Chunxiang, Y. Shuli, Chin. J. Chem. 2010, 28, 1525.

[25] K. L. Liu, W. F. Chen, Q. Y. Jiang, X. F. Bai, Z. F. Li, Z. Xu, L. W. Xu, ChemCatChem 2016, 8, 1495.

[26] B. M. Trost, D. L. van Vranken, Chem. Rev. 1996, 96, 395.

[27] Y. Gök, J. Van der Eycken, Helv. Chim. Acta 2012, 95 , 831.

[28] R. Noyori, S. Hashiguchi, Acc. Chem. Res. 1997, 30, 97.

[29] J. Margalef, T. Slagbrand, F. Tinnis, H. Adolfsson, M. Dieguez, O. Pamies, Adv. Synth.\& Catal. 2016, 358, 4006.

[30] S. E. Clapham, A. Hadzovic, R. H. Morri,s, Coord. Chem. Rev. 2004, 248, 2201.

[31] J. S. M. Samec, J. E. Bäckvall, P. G. Andersson, P. Brandt, Chem. Soc. Rev. 2006, 35, 237.

[32] T. Ikariya, A. Blacker, Acc. Chem. Res. 2007, 40, 1300.

[33] C. Wang, X. Wu, J. Xiao, Chem. Asian. J. 2008, 3, 1750.

[34] K. Everaere, A. Mortreux, J.F. Carpentier, Adv. Synth. Catal. 2003, 345, 67.

[35] S. Phothongkam, B. J. Uang, Asian J. Org. Chem. 2015, 4, 794.

[36] D. Wang, D. Astruc, Chem. Rev. 2015, 115, 6621.

[37] P. N. Liu, J. G. Deng, Y. Q. Tu, S. H. Wang, Chem. Commun. 2004, 2070.

[38] J. H. Li, Y. F. Tang, Q. W. Wang, X. F. Li, L. F. Cun, X. M. Zhang, J. ZhuL. C. Li, J. G. Deng, J. Am. Chem. Soc. 2012, 134, 18522

[39] T. Touge, T. Hakamata, H. Nara, T. Kobayashi, N. Sayo, T. Saito, Y. Kayaki, T. Ikariya, J .Am. Chem. Soc. 2011, 133, 14960.

[40] O. Dayan, B. Cetinkaya, J .Mol. Catal. A Chem. 2007, 271, 134.

[41] H. Vazquez-Villa, S. Reber, M. A. Ariger, E. M. Carreira, Angew. Chem. Int. Ed. 2011, 50, 8979.

[42] W. Baratta, M. Bosco, G. Chelucc, A. Del Zotto, K. Siega, M. Toniutti, E. Zangrando, P. Rigo, Organometallics 2006, 25, 4611.
[43] H. Wei, Z. Bangle, L. Peng, S. Xiaoli, Z. Shengyong, Chin. J. Catal. 2006, 27, 527.

[44] X. Liu, T. Zhang, Y. Hu, Shen. Catal. Lett. 2014, 144, 1289.

[45] P. Kumar, A. Kumar Singh, M. Yadav, P. Z. Li, S. Kumar Singh, Q. X, u, D. Shankar Pandey, Inorg. Chim. Acta. 2011, 368, 124.

[46] Y. Gök, U. Karayigit, H. Z. Gök, J. Organometal. Chem. 2017, 846, 44.

[47] Y. Gök, S. Küloglu, H. Z. Gök, L. Kekeç, Appl. Organometal. Chem. 2014, 28, 835.

[48] Y. Gök, S. Kıllıçarslan, H. Z. Gök, . U. Karayigit, Chirality 2016, 28, 593.

[49] Terfort, A.; Brunner, H. J. Chem. Soc. Perkin. Trans. 1996, 1, 1467.

[50] S. M. Shin, D. Moon, K. S. Jeong, J. Kim, P. K. Thallapally, N. Jeong, Chem. Commun. 2011, 47, 9402.

[51] D. A. Evans, K. R. Campos, J. S. Tedrow, F. E. Michael, M. R. Gagné, J. Am. Chem. Soc. 2000, 122, 7905.

[52] A. Agac, I. Karakaya, I. Sahin, S. Emir, S. Karabuga, S. Ulukanlı, J. Organomet. Chem. 2016, 819, 189.

[53] S. Gladiali, E. Alberico, Chem. Soc. Rev. 2006, 35, 226.

[54] F. Foubelo, C. Najera, M. Yus, Teterahedron Asymmetry 2015, 26, 769.

[55] I. G. Rios, A. Rosas-Hernandez, E. Martin, Molecules 2011, 16, 970.

[56] B.M. Trost, X. Ariza, J. Am. Chem. Soc. 1999, 121, 10727.

[57] B.M. Trost, C.Heinemann, X. Ariza, S.Weigand, J.Am, J. Chem. Soc. 1999, 121, 8667.

[58] Y. Tanaka, T. Mino, K. Akita, M. Sakamoto, T. Fujita, J. Org. Chem. 2004, 69, 6679.

[59] [59] S. Vyskocil, S. Smrcina, V. Hanus, M. Polasek, P. Kocovsky, J. Org. Chem. 1998, 63, 7738.

[60] M. X. Sun, J. Campbell, G. Kang, W. H. G. Wang, B. K. $\mathrm{Ni}$, J. Organometal. Chem. 2016, 810, 12.

[61] A.M. Maj, K.M. Pietrusiewicz, I. Suisse, F. Agbossou, A. Mortreux, Tetrahedron: Asymmetry 1999, 10, 831. 